University for Business and Technology in Kosovo

UBT Knowledge Center

UBT International Conference

2012 UBT International Conference

Nov 2nd, 9:00 AM - Nov 3rd, 5:00 PM

\title{
3 MONT - System for Energy Saving in Building
}

Driton R. Kryeziu

University for Business and Technology

Bojan Bratuž

TKK Srpenica

Alojz Nastran

TKK Srpenica

Binak Beqaj

University for Business and Technology, binak.beqaj@ubt-uni.net

Follow this and additional works at: https://knowledgecenter.ubt-uni.net/conference

Part of the Architecture Commons

\section{Recommended Citation}

Kryeziu, Driton R.; Bratuž, Bojan; Nastran, Alojz; and Beqaj, Binak, "3 MONT - System for Energy Saving in Building" (2012). UBT International Conference. 6.

https://knowledgecenter.ubt-uni.net/conference/2012/all-events/6

This Event is brought to you for free and open access by the Publication and Journals at UBT Knowledge Center. It has been accepted for inclusion in UBT International Conference by an authorized administrator of UBT Knowledge Center. For more information, please contact knowledge.center@ubt-uni.net. 


\title{
3 MONT - System for energy saving in buildings
}

\author{
Driton R. Kryeziu ${ }^{12}$, Bojan Bratuž ${ }^{1}$, Alojz Nastran ${ }^{1}$ and Binak Beqaj ${ }^{2}$, \\ ${ }^{1}$ TKK Srpenica d.d.- Slovenija \\ ${ }^{2}$ University for Business and Technology-Prishtinë
}

\begin{abstract}
One of the main goals of the European Union is to reduce energy consumption and to increase energy efficiency on buildings. More than $40 \%$ of prime energy in EU is consumed in buildings. Because of that EU has introduced legislation to ensure that they consume less energy. The keypart of this legislation is energy performance of buildings directive, EPBD. EPBD requires from all EU countries to enhance their building regulations and to introduce energy certification schemes for buildings. Just through windows and doors, which are part of the exterior wall of a building, we can lose more than $20 \%$ of all energy for heating. In order to achieve better heat insulation, it is very important not just to replace old windows with new better-insulated ones, but also how we install them. According to new demands the junction between construction wall and window must be airtight, resistant to different types of weather and flexible because of the construction movement. Using only classical polyurethane foam for energy efficient installation of windows is not sufficient any more. Using 3MONT system for energy efficient installation of windows and exterior doors developed in TKK Srpenica we can achieve ten times better air tightness according to classical polyurethane foam. The whole system is fully elastic and resistant to heavy weather. It fulfills all new standards of energy efficient installation by demonstrating certificates of four recognized institutes.
\end{abstract}

Keywords: Energy efficient, performance buildings, EPB directive, installing windows, 3MONT system

\section{European energy policy}

\subsection{Europe energy dependence}

Europe is faced with increasing energy dependence and at the same time it has very limited natural resources. European energy policy's goal until 2020 is to reduce gas emissions of $\mathrm{CO}_{2}$ for $20 \%$, increase energy efficiency of buildings for $20 \%$ and increase use of renewable energy with 2005 as a base year.

\subsection{Energy consumption in buildings}

One of the main goals of European Union is to reduce energy consumption and to increase energy efficiency of buildings. More than $40 \%$ of prime energy in EU-27 is consumed in buildings. Only in households it is consumed $25 \%$ (2007) of all prime energy from which $75 \%$ is used for heating. Because of that EU has introduced legislation to ensure that they consume less energy. The key part of this legislation is Energy Performance of Buildings Directive EPBD. EPBD requires from all EU countries to enhance their building regulations and to introduce energy certification schemes for buildings. 


\section{Heat losses in buildings}

\subsection{Factors affecting energy consumption in buildings}

The following properties of building are to be considered by EPBD:
a. Natural, mechanical ventilation and air tightness
b. Thermal properties of building
- Thermal capacity
- Thermal insulation
- Passive heating
- Thermal bridges
c. Building orientation
d. Passive solar systems, protection against solar radiation

\subsection{Heat losses through windows and external doors}

The heat losses in buildings generally occur through exterior walls, windows and roofs. Just through windows and doors, which are part of the external envelope of buildings, we can lose more than $20 \%$ of all energy for heating.

Excellent thermal insulated windows and external doors for passive houses has thermal conductivity approx. $0,7 \mathrm{~W} / \mathrm{m}^{2} \mathrm{~K}$, which is still three times more than $40 \mathrm{~cm}$ thick external wall with thermal conductivity $0,28 \mathrm{~W} / \mathrm{m}^{2} \mathrm{~K}$.

What about joints between windows/external doors and wall construction?

Window and door frame sealing has great affect on efficient use of energy for thermal heating. Incorrect mounting of windows and doors can thus, besides significant heat losses, lead to damages resulting from vapor infiltration through the joint and wall. Consequently, the tightness of joints has to be ensured with correct material.

Figure 1: taken with thermal imaging camera, shows thermal loses through external envelope of building. Most of energy for heating is lost through windows and junction between window frame and building construction.

Figure 2: shows thermal image of building after renovation with low thermal loses through windows.
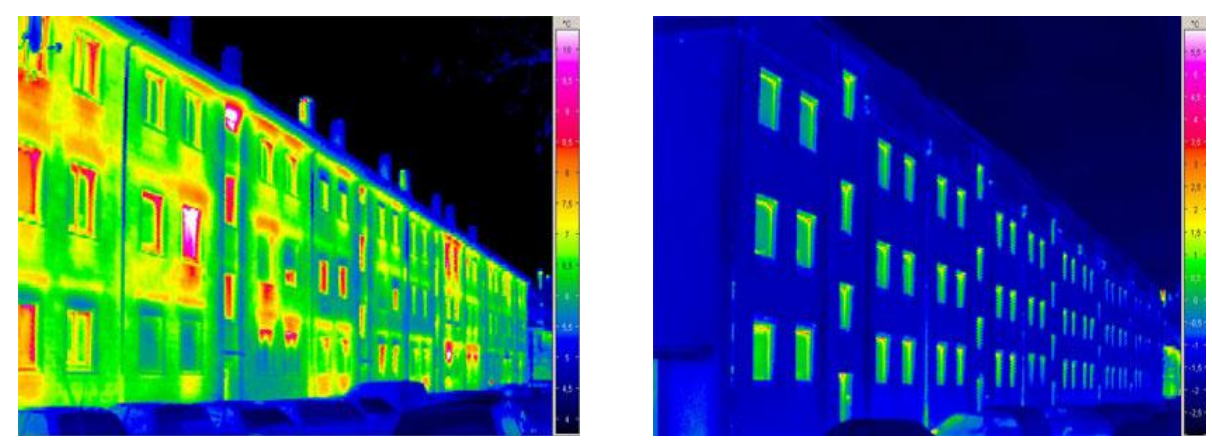
Figure 1: before renovation

Figure 2: after renovation

\subsection{Installation of windows and external doors according to RAL guideline}

With the development of contemporary thermal insulation windows with minimum air permeability, the attention has been drawn to how properly install these windows into walls. According to new demands the junction between construction wall and window must be airtight, resistant to different types of weather and flexible because of the construction movement. Using only classical polyurethane foam for energy efficient installation of windows is not sufficient any more.

The installation guideline issued by RAL Gutegemainschaft Fenster und Haustüren e.V. in 2010 can be used. The guideline contains the basis of proper mounting of windows, doors and the corresponding mounting frames, and is as such a practical guide for architects, planners, foremen and fitters.

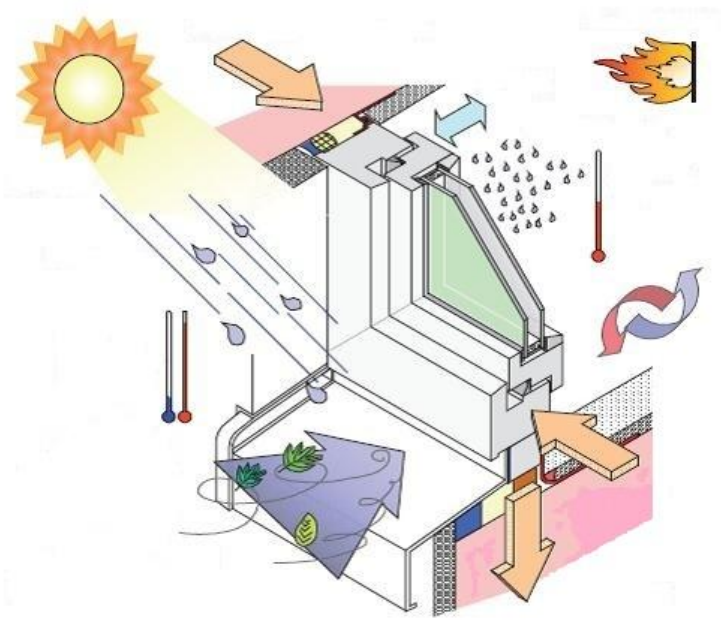

Figure 3: The junction between window frame and construction must withstand all main loads: wind, UV radiation, extreme temperatures, dilatation of the different materials, fire and high concentration of humidity

\section{MONT system for energy efficient installation of windows and exte rnal doors}

\subsection{Sealing systems}

There are different ways, tested in practice, of how to professionally seal the final joints between window or door frames and wall construction. Basic suitability of the system has to be planned for each individual case. Nevertheless, the decision on which system to choose depends on the individual and the materials we are sealing. 


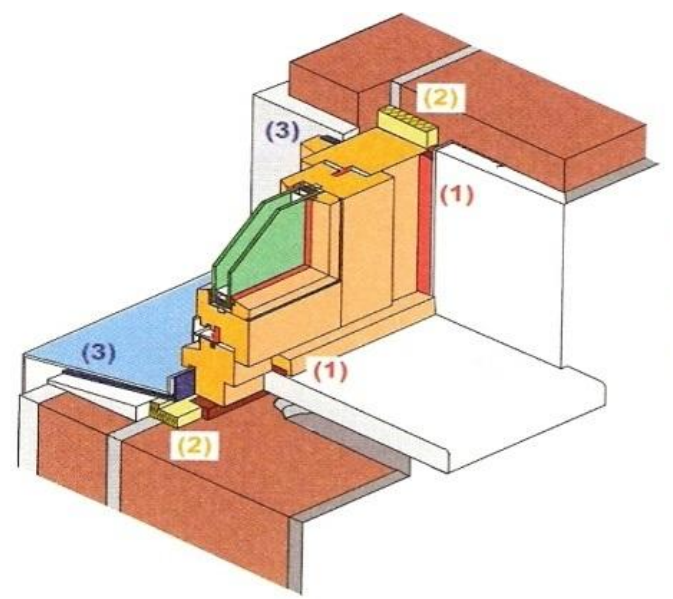

Figure 4: according to RAL guideline, the joint is divided into three levels.
a. $1^{\text {st }}$ level, interior sealing has to be air and vapor tight
b. $2^{\text {nd }}$ level represents thermal and sound insulation
c. $\quad 3^{\text {rd }}$ level, exterior sealing represents a barrier for wind and rain and has to be vapor permeable.

\subsection{MONT system basics}

In TKK Srpenica we seriously approach to solving the problem how to make a certified system for energy efficient installation of windows/external doors into wall construction.

Because of investigation, we developed 3MONT system certified by four recognized institutes (IFT Rosenheim, MPA BAU Hannover, ZAG Ljubljana and TU Graz). The whole system is fully elastic and resistant to heavy weather. It fulfills all new standards of energy efficient installation.

Table 1: 3MONT system is based on three levels sealing of joint according to RAL guideline.

\begin{tabular}{ccc}
\hline 1st Level & 2nd Level & 3rd Level \\
Interior sealing & $\begin{array}{c}\text { Sound and thermal } \\
\text { insulation }\end{array}$ & Exterior sealing \\
\hline $\begin{array}{c}\text { 3MONT TRAK IN } \\
\text { or } \\
\text { 3MONT KIT IN }\end{array}$ & 3MONT PU FLEX & 3MONT TRAK OUT \\
or \\
3MONT KIT OUT
\end{tabular}




\subsection{Materials used in 3MONT systems}

a) 3MONT TRAK is a system for rapid and safe sealing of window joints: for vapor tightness on the INside and vapor permeability on the OUTside. Both tapes are fully elastic in every direction and are permanently resistant to any movement accommodation grade. Both sealing tapes can be plastered over and painted. 3MONT TRAK is classified as E class by standard DIN EN 13501-1.

b) 3MONT PU FLEX is gun grade one-component polyurethane foam with very high elasticity used for thermal insulation (DIN 18542:2009-7; a $<0,1 \mathrm{~m} 3 /\left[\mathrm{h} \cdot \mathrm{m}(\mathrm{daPa})^{2 / 3}\right]$ and sound insulation. Comparing to the other kinds of polyurethane foam, it can hold out higher movement accommodation. It adheres to most building materials.

c) 3MONT KIT is an elastic sealant with different moisture vapor transmission rate for INside $(\mu=1600)$ and OUTside $(\mu=966)$ sealing, with movement accommodation up to $25 \%$ according to standard ISO 11600. It has excellent adhesion on different surfaces and is resistant to mold.

Sealants must always be used in combination with a nonabsorbent material, to achieve proper sealing of joints.

\subsection{Advantages of 3MONT systems}

System's testing done by Slovenian National building and Civil engineering institute ZAG shows ten times better air tightness of joint between window frame and wall construction sealed with 3MONT system compared to the joint sealed with classical polyurethane foam.

Table 2: Test results of air tightness according to standard SIST EN 1026: 2001 and SIST EN 1027

\begin{tabular}{|c|c|c|}
\hline Material used & Classical PU foam & 3MONT system \\
\hline $\begin{array}{l}\text { sealing } \\
\mathrm{dP}(\mathrm{Pa})\end{array}$ & $\mathrm{V}_{\text {air }}\left(\mathrm{m}^{3} / \mathrm{h}\right)$ & $\mathrm{V}_{\text {air }}\left(\mathrm{m}^{3} / \mathrm{h}\right)$ \\
\hline 50 & 0,232 & 0,016 \\
\hline 100 & 0,346 & 0,028 \\
\hline 150 & 0,436 & 0,040 \\
\hline 200 & 0,515 & 0,050 \\
\hline 250 & 0,585 & 0,061 \\
\hline 300 & 0,649 & 0,071 \\
\hline 450 & 0,819 & 0,081 \\
\hline 600 & 0,966 & 0,090 \\
\hline 750 & 1,097 & 0,099 \\
\hline 900 & 1,218 & 0,109 \\
\hline 1050 & 1,331 & 0,118 \\
\hline 1200 & 1,437 & 0,127 \\
\hline
\end{tabular}



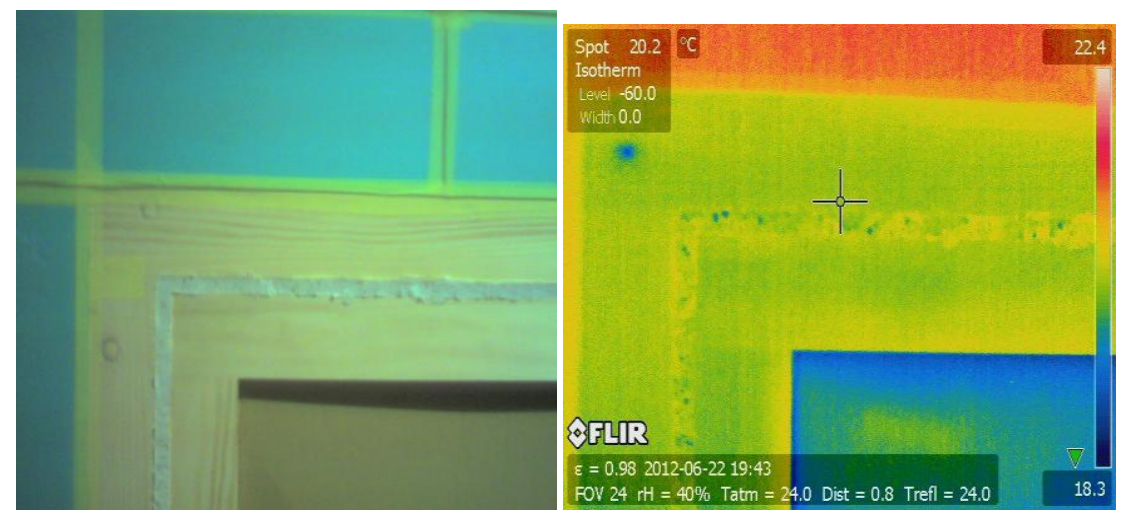

Figure 5: Thermal image of joint sealed with classical PU foam shows heat losses
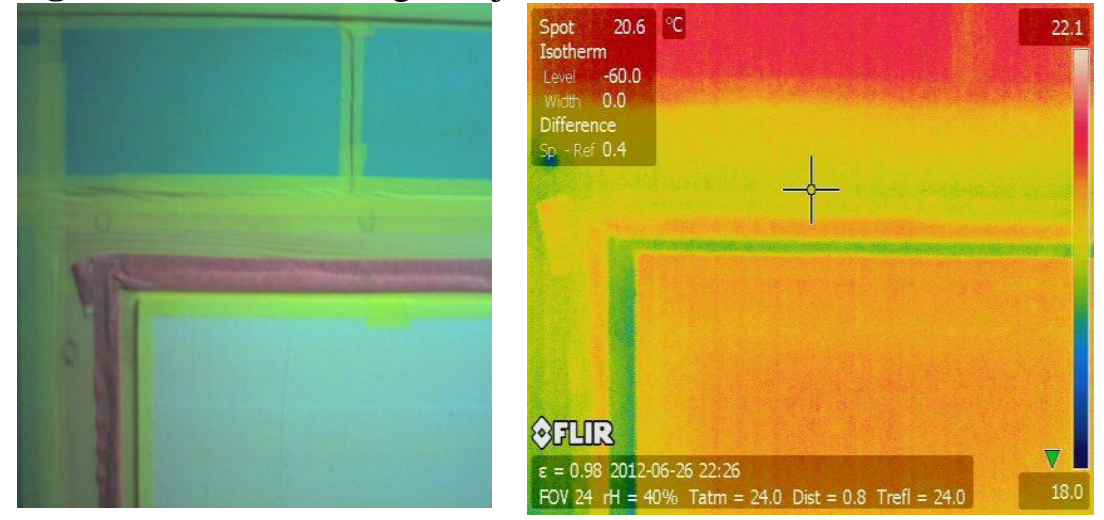

Figure 6: Thermal image of joint sealed with 3MONT system shows excellent heat insulation
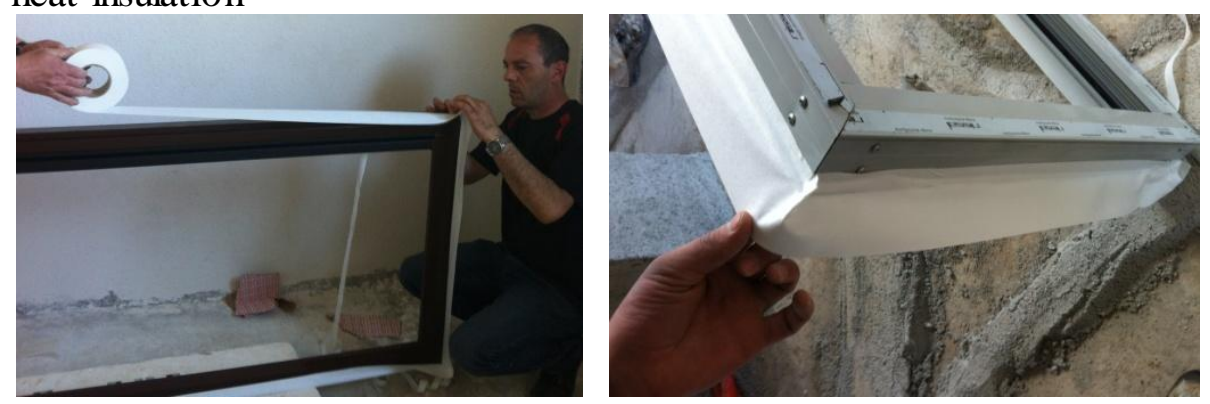

Figure 7: Thermal image of joint sealed with 3MONT system, 3MONT TRAK OUT

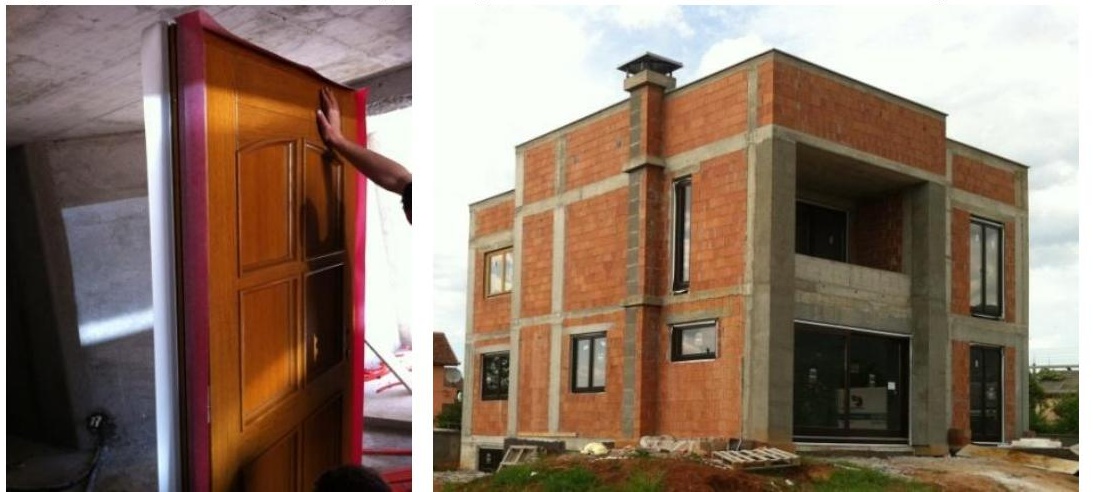


Figure 8: Thermal image of joint sealed with 3MONT system, 3MONT TRAK IN and 3MONT TRAK OUT - practical study, Prizren

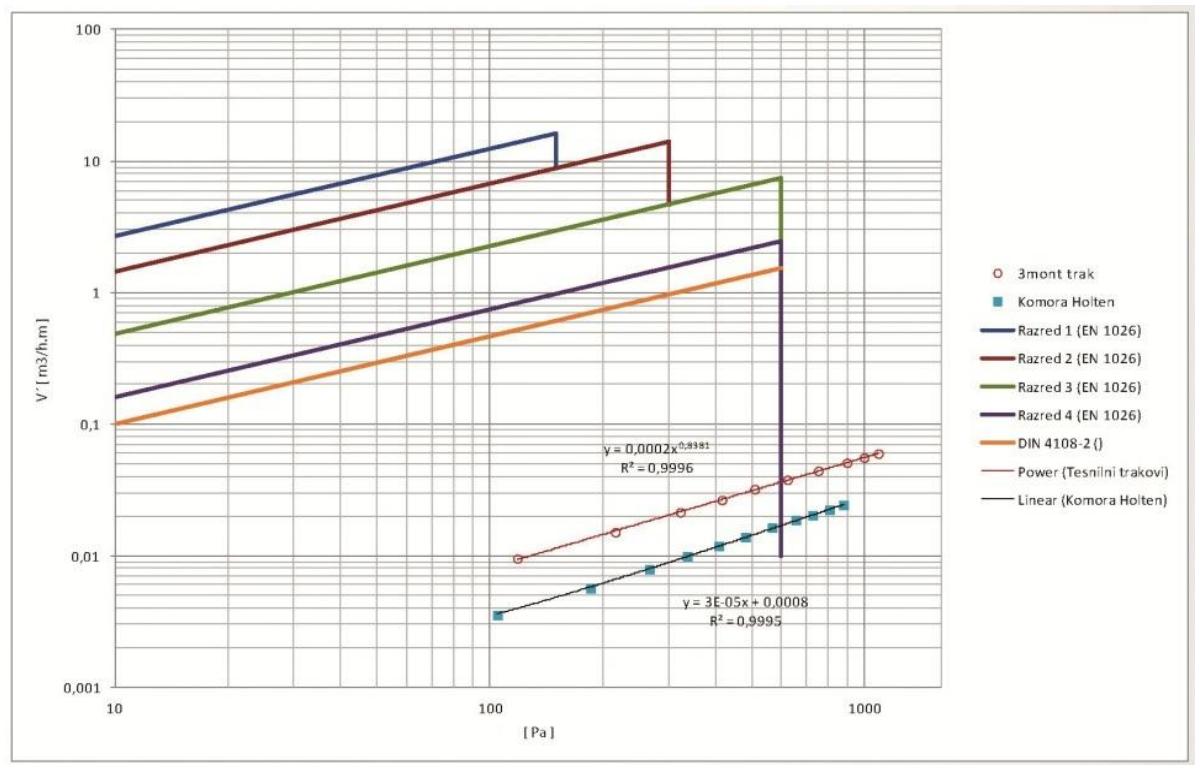

Figure 9: Test results show that 3MONT system meets and exceeds all requirements of energy efficient installation of window and external doors into wall construction according to standard EN 1026 and DIN 4108 part 2. 


\section{Conclusions}

Buildings will have an impact on long-term energy consumption; therefore, new buildings should meet minimum energy performance requirements tailored to the local climate. Best practice should in this respect be geared to the optimum use of factors relevant to enhancing energy performance. By using 3MONT system for sealing joints between windows or external doors and wall construction we easily fulfill all new standards and requirements for energy efficient installation and it is tested to withstand all climate conditions. Because of its complete elasticity it can be used at replacing old windows with new windows or at installation of high thermal insulation windows in new energy efficient buildings.

\section{References}

[1] RAL - Gütegemeinschaft Fenster und Haustüren e.V., (2010) Leitfaden zur Planung unad Ausführung der Montage von Fenstern und Haustüren, Frankfurt

[2] Fouad N.A., Richter T. (2006) Leitfaden Thermografie im Bauwesen, Fraunhofer IRB Verlag, Stuttgart

[3] Šijanec Zavrl M., in sod. (2012) Energetska učinkovitost in energteska izkaznica stavb, Založba Forum media, Maribor

[4] TKK internal documents

[5] Directive 2002/91/ EC of the European Parliament and of the Council of 16 December 2002 on the energy performance ofbuilding 